\section{PROGRESSION MARKERS IN VIETNAMESE NARRATIVE}

\section{Somsonge Burusphat ${ }^{1}$}

\begin{abstract}
This article aims to study the progression markers in six Vietnamese folktales. Progression markers refer to the grammatical devices that characterize any happenings that push the story forward. These markers highlight the temporal sequence of succeeding events, which form the backbone, or storyline of the Vietnamese folktales. They are rồ $i$ 'already', xoan 'finish', đoan 'end, terminate', thì 'then', bèn 'then, consequence', and đã 'have experienced'. The paper begins with the structural description of these progression markers and proceeds to their discourse functions both on the narrative timeline and out of the line. As the default timeframe of the narrative is past time or accomplished time, when these markers occur in past time, they indicate temporal succession and a cause-effect relationship of foregrounded events. In projected time as in quotations, the progression markers rồi, xoan, đoạn, thì, bèn, and đã are compared with the progression markers

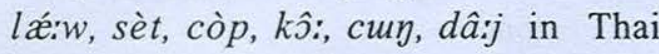
respectively to show that despite the morphological difference, at the level of discourse syntax, their discourse structures are quite common.
\end{abstract}

${ }^{1}$ Professor, Institute of Language and Culture for Rural Development, Mahidol University.

\section{Introduction}

Certain events in a narrative discourse are given special prominence within that discourse. They are more important to the development of the plot or theme of the narrative than are others. These events are sequenced and chronologically ordered, i.e., the first point mentioned precedes the second in the narrative timeline. Longacre $(1996: 9)$ posits the temporal succession or temporal sequence as "a framework of temporal succession in which some of the events or doings are contingent on previous events or doings." The framework of temporal succession characterizes the narrative. The events or situations on the narrative timeline are represented as having already taken place and usually narrated in the simple past or historical present tense.

Dry (1983) mentions that the more important happenings are reported in foreground clauses-clauses in which the action of the narrative takes up and time begins to move forward. The foreground clauses make reference to sequenced temporal points, rather than spans of time, and these points are usually the endpoints of situations. These clauses are on a narrative timeline and constitute the foreground of a narrative.

This paper $^{2}$ focuses on the progression

${ }^{2}$ The author would like to thank Sophana Srichampa for the discussion of meanings of some Vietnamese words and Megan Sinnott for editing the first draft of this paper. My thanks also go to Suksiri Danthanavanich for providing me with valuable data and for her effort in transcribing the folktales written in Vietnamese into phonetic symbols and translating them into English. 
markers which accompany foreground clauses. The progression markers refer to the grammatical devices that characterize any happenings that push the story forward. These markers highlight succeeding events which form the backbone or storyline of the Vietnamese narrative. They are temporal connectives and the aspectual value of clauses. The paper begins with a structural description of the progression markers and proceeds to their discourse functions both on the narrative timeline $^{3}$ and out of the line. The discussion part gives a summary of the findings in comparison with Thai.

The data consist of six Vietnamese folktales drawn from the work "Cohesive devices in Vietnamese folktales" (Suksiri, 2000). These folktales were transcribed into phonetic symbols and translated into English from the original work Kho Tàng Truyện Cổ Tịch Việt Nam (A Collection of Vietnamese Folktales) (Nguyễn Ván Ngọ, Vũ Ngọ Phan, and Trầ Thanh Mại, 1996).

\section{Structural Description}

The progression markers which identify sequenced points on the narrative timeline include the words rồi, xong, đoạn, đã , bèn and thì. Of all progression markers rồi occurs with most frequency whereas doan has the least occurrence, as shown below:

3 The narrative time-line is defined as a chronological theme-line along which narrative develops. The timeframe of the narrative is usually in the past. Time refers to "all the days of the past, present, and future" (Hornby et al, 1962:1057).

\begin{tabular}{|c|c|}
\hline $\begin{array}{c}\text { Progression } \\
\text { markers }\end{array}$ & $\begin{array}{c}\text { Number of } \\
\text { occurrences }\end{array}$ \\
\hline rồi & 35 \\
\hline thì & 25 \\
\hline đã & 19 \\
\hline bèn & 14 \\
\hline xong & 13 \\
\hline doạn & 6 \\
\hline
\end{tabular}

The meanings of these words which are relevant to this study are given in the Vietnamese-English Dictionary (Viện Ngôn ng học, 1987) as listed below. The examples are drawn both from the dictionary and Sophana (p.c.).

rồ 1 1. 'Already, done, over, finished'

e.g., Tồi ăn sáng rồi. I have breakfast already 'I've already had breakfast.'

2. 'Then'

e.g., Tập thể duc rồi

Exercise already

mới ăn

just have

lót da.

breakfast

'To do one's morning exercises then have breakfast.'

xong 'Be complete, be finished, be done'

e.g., $\quad$ làm luán án
young sibling do thesis
xong chua?
finish yet
'Have you finished your thesis
yet?'


doạn 1. (rare)

a. 'Finish, just finish'

e.g., Chúngta gặt hái

We harvest

vùa doạn.

just finish

'We've just finished the harvest.'

b. 'Cut off, break off, terminate'

e.g., Tôi doạn tình với
I break off love with
Lan rồi.
Lan already
'I've already broken off the love
affair with Lan.'

2. 'Then'

e.g., Chúng tôi nói chuyện

We speak story

đến khuya, đoạn

until late at night then

chia tay nhau

say good-bye each other

'We talked until midnight and

then separated.'

đã 'Already'

$\begin{array}{lll}\text { e.g., Anh } & \text { ban } & \text { đã } \\ & \text { elder sibling } & \text { friend already }\end{array}$

đến rồi.

arrive already

'Our friend has arrived.'

e.g., Tháng này sang năm

month this next year

cuốn tù điển đã

CLF. dictionary already

soan xong.

compile finish

'This month next year, the dictionary will have been

finished.'

Bèn 'Then'
e.g., Thấy không khí
see atmosphere
nặng nề quá anh ta
strained too he
bèn nói đùa một câu.
then joke 1 sentence
'As he noticed that the
atmosphere was quite strained, he
then cracked a joke.'

Thì 1. 'Then'

e.g., Khát nước thì uống

thirsty then drink

nước nguồn.

water source

'If one is thirsty, then one can drink water from the source.'

2. 'As for'

$\begin{array}{lll}\text { e.g., } & \text { Cơm thì hẩm, } \\ \text { rice } & \text { as for mouldy }\end{array}$

cà thì mốc

egg-plant as for mouldy

'As for the rice, it is rotted, as for the egg-plant, it is mouldy.'

Based on their occurrences in the above examples and the folktales, the syntactic structure of the words rồi, xong, đoạn is postverbal; đã, bèn are preverbal ${ }^{4}$; and thì is a sentence conjunctive and topic marker. The progression markers rồi, xong, đoạn, thì and bèn usually occur in a series of clauses whereas $d \tilde{a}$ usually

\footnotetext{
${ }^{4}$ Sophana (p.c.) notes that $\tilde{n} a \tilde{o}$ also occurs after a clause as an adverb meaning 'first of all' as in the following example:

Nghî một cái đã.

rest a while first of all

'Let's take a rest first.'
} 
occurs in a single clause as illustrated by the examples below: ${ }^{5}$

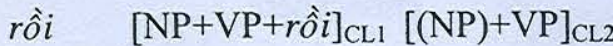

Lac Long Quân đóng một
Lac Long Quan build one
chiếc thuyề thật
CLF boat real
chắc và thât lớn,
strong and real big
rèn một khối sắt có
forge one CLF iron have
nhiều canh sắc nung
many sharp edge burn
cho thất đỏ rỏi
to real red COMP.MK
dem khối sắt
carry CLF iron
xuống thuyền chèo
down boat row
thẳng đến NguTinh.
straight to Ngu Tinh
'Lac Long Quan built a big and
strong boat, forged a block of iron
that was full of the sharp points,
heated it until it was red and
brought it along to the evil fish's
cave.'

${ }^{5}$ The abbreviations used in this paper are:

$\mathrm{CL}$ clause

CLF classifier

COMP.MK completive marker

$1^{\text {st }}$ PER first person pronoun

FUT.MK future marker

NP

PASS.MK

$3^{\text {rd }}$ PER

noun phrase

passive marker

TOP.MK

VP

third person pronoun

topic marker

verb phrase

YO.SIS

younger sister xong $\quad[\mathrm{NP}+\mathrm{VP}+\text { xong }]_{\mathrm{CL} 1}[(\mathrm{NP})+\mathrm{VP}]_{\mathrm{CL} 2}$

(2)

$\begin{array}{lcl}\text { Lý Thông } & \text { nghe } & \text { xong, } \\ \text { Ly Thong } & \text { listen } & \text { COMP.MK }\end{array}$

nẩy ra một múu

bounce out one trick

Thâm độc

wicked

'After Ly Thong had listened, he tried a trick to intimidate Thach Sanh.'

doạn $[(\mathrm{NP})+\mathrm{VP}+\text { doạn }]_{\mathrm{CL} 1}[(\mathrm{NP})+\mathrm{VP}]_{\mathrm{CL} 2}$

Nói doạn, hai me speak COMP.MK two mother con quầnáo xúngxính child clothes beautiful

lên đường

up way

'After that was said, Cam and her mother went to the festival in their new dresses.'

thì

$[\mathrm{NP}+\mathrm{VP}]_{\mathrm{CL} 1}$ thi $[(\mathrm{NP})+\mathrm{VP}]_{\mathrm{CL} 2}$

(4)

$\begin{array}{ll}\text { Sanh binhtĩnh, } & \text { hóa phép } \\ \text { Sanh calm, } & \text { use magic } \\ \text { Đánh nhau } & \text { với } \\ \text { fight together with }\end{array}$

trăn tinh, hồi lâu thì

python, long while then

yêu quái $\quad b i$

evil spirits PASS.MK

giết chết, hóa ra một

kill die, change out one

con trăn lớn.

CLF python big

'Thach Sanh stayed calm and fought it with his magical powers, then the evil spirit was killed and changed into a big snake.' 
bèn $\quad[\mathrm{NP}+\mathrm{VP}]_{\mathrm{CL} 1}[(\mathrm{NP})+b \grave{n} n+\mathrm{VP}]_{\mathrm{CL} 2}$

Thấy có quán nước
see have shop water
bên đườn sachsẽ,
beside way clean

bèn ghé vào.

then drop in

'He saw a clean teashop at the side of the path, so he stopped at that shop.'

đã $\quad[\mathrm{NP}+d \tilde{a}+\mathrm{VP}]_{\mathrm{CL}}$

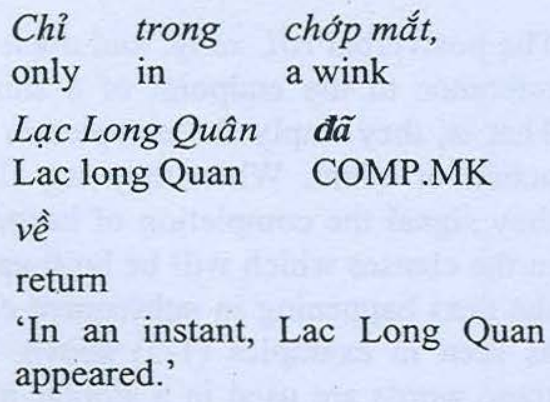

The progression markers may co-occur. Rồi occurs with all other progression markers. Thì also co-occurs with most of the progression markers except xong. ${ }^{6}$ And $d \tilde{a}$ can occur with xong. The following examples illustrate some of the cooccurrences:

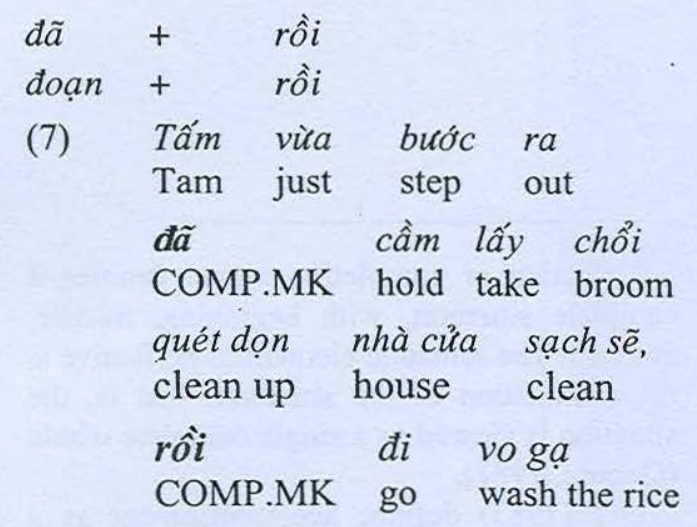

${ }^{6}$ The non-co-occurrence of thi and xong may be due to the limitation of data.

\begin{tabular}{|c|c|c|}
\hline $\begin{array}{l}\text { thổi corm, } \\
\text { cook a meal }\end{array}$ & $\begin{array}{ll}o m, & \text { hái } \\
\text { a meal } & \text { pluck }\end{array}$ & $\begin{array}{l}\text { rau } \\
\text { vegetable }\end{array}$ \\
\hline $\begin{array}{l}\partial^{2} \\
\text { at }\end{array}$ & $\begin{array}{ll}\text { vườn } & \text { nấu } \\
\text { garden } & \text { cook }\end{array}$ & $\begin{array}{l}\text { canh } \\
\text { soup }\end{array}$ \\
\hline $\begin{array}{l}\text { giúp } \\
\text { help }\end{array}$ & $\begin{array}{l}\text { bà } \\
\text { old woman }\end{array}$ & $\begin{array}{l}\text { hàng } \\
\text { shop }\end{array}$ \\
\hline $\begin{array}{l}\text { nuoóc } \\
\text { water }\end{array}$ & $\begin{array}{l}\text { doan } \\
\text { COMP.MK }\end{array}$ & $\begin{array}{l}\text { Tấm } \\
\text { Tam }\end{array}$ \\
\hline $\begin{array}{l}\text { lại } \\
\text { again }\end{array}$ & $\begin{array}{ll}\text { thu } & \text { hin } \\
\text { get back } & \text { boc }\end{array}$ & \\
\hline $\begin{array}{l}\text { bé } n h \\
\text { little }\end{array}$ & $\begin{array}{l}2 \text { nhu cũ rồi } \\
\text { as old } \mathrm{CON}\end{array}$ & MP.MK \\
\hline $\begin{array}{l}\text { chui } \\
\text { creep }\end{array}$ & $\begin{array}{ll}\text { vào } & v o ̉ \\
\text { into } & \text { peel }\end{array}$ & $\begin{array}{l}q u a ̉ \\
\text { CLF }\end{array}$ \\
\hline
\end{tabular}

'As soon as Tam stepped out, she held a broom cleaning the house and cooking for the old woman. And then she returned into the fruit.'

xong + rồi

(8)

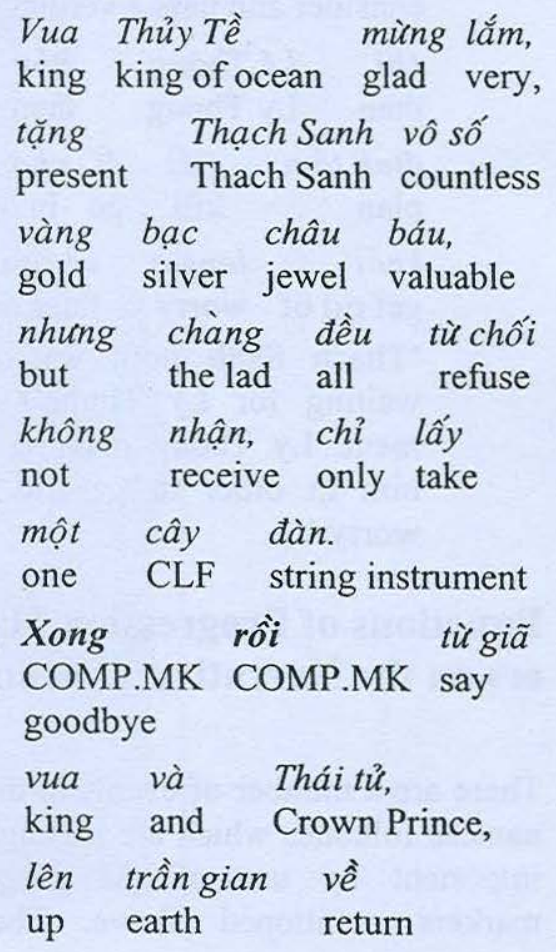




$$
\begin{array}{ll}
\begin{array}{ll}
\text { chốn cũ } & \multicolumn{3}{l}{} \\
\text { place old } & \text { at } \\
\text { gốc } & \text { đa } \\
\text { base of tree } & \text { banyan tree }
\end{array}
\end{array}
$$

'The king was very glad. He gave Thach Sanh countless gold, silver and jewels but Thach Sanh did not accept anything except a stringed instrument. Afterwards Thach Sanh said goodbye to the king and the Crown Prince and returned home.'

thì + bèn

(9)

$$
\begin{aligned}
& \text { Kịp chođến khi } \\
& \text { in time until time } \\
& \text { Thach Sanh bi } \\
& \text { Thach Sanh PASS.MK } \\
& \text { bắt giao Cho } \\
& \text { catch assign to } \\
& \text { Lý Thông } \\
& \text { Ly Thong } \\
& \text { xét xủ, }
\end{aligned}
$$
consider and pass a verdict on,

thì LýThông bèn
then LyThong then

địn tâm giết đi cho plan kill go in order to khỏi longại vềsau. get rid of worry later on 'Thach Sanh now was in jail waiting for Ly Thong's judgement. Ly Thong planned to kill him in order to get rid of his worry.'

\section{Functions of Progression Mark- ers on the Narrative Timeline}

There are a number of events in the Vietnamese folktales which are highlighted as important by use of the progression markers mentioned above. Therefore, such events, when taken together as a group, represent a high-level abstraction of the folktales, in which only the most important events are mentioned.

The general function of the progression markers is therefore to highlight and mark thematic events which are temporally sequenced. The meanings of progression markers drawn from the VietnameseEnglish Dictionary (1987) above either indicate perfective (completive) aspect ${ }^{7}$ or temporal succession.

The postverbal rồi, xong, and đoạn make reference to the endpoint of a situation. That is, they imply the completion of an action or event. When they tag clauses, they signal the completion of happenings in the clauses which will be built upon by the next happening in subsequent clauses as seen in examples (1-3) above. These three words are used in a similar manner and it is difficult to figure out when to use each word. However, it is more likely that xong is used with an accomplishment verb ${ }^{8}$ and doan is used to terminate a happening whereas rồi has a wider usage with various kinds of verbs indicating the completion of a happening.

\footnotetext{
${ }^{7}$ Perfective or completive aspect denotes a complete situation, with beginning, middle, and end. The semantic element of perfective is the termination of the situation; that is, the situation is viewed as a single complete whole (Comrie, 1981).

${ }^{8}$ Dry (1983) defines accomplishment as a situation of some duration, having a natural endpoint, outcome, or result state, e.g., building a house, running a mile, singing a song.
} 
The sentence conjunctive thi and the preverbal bèn introduce a succeeding event which builds upon the preceding event usually encoded by an adverbial clause. It can be seen that these two words have the same function. The difference is their syntactic structure: thi occurs between clauses and bèn before a verb as seen in example (9). Besides the structural difference, bèn has a slightly different use than thì in that bèn implies a consequence of the previous event. It should be noted also that bèn is no longer used in everyday conversation. It appears only in old texts. The sentence conjunctive thi seems to play a more important role in the discourse.

The following example presents a chain of events marked by bèn and rồi, each one of which in turn is built upon. (10) a. Tin là thật, Tấm
believe be real Tam 'Tam believed her sister's words.'

b. bèn xuống ao lội then down pond swim ra chố sâu tắm rưa out place deep wash 'Then she went down to the pond and washed her hair.'

c. Cám thù̃a dịp

Cam take the opportunity

trút hết tép của

pour finish tiny shrimp of

Tấm vào giỏ của

Tam into basket of

Mình rồi

oneself already

'Cam transferred the tiny shrimp from Tam's basket to hers.' $\begin{array}{ll}\text { d. ba chân bốn cẳng } & \text { về } \\ \text { run at full speed } & \text { return }\end{array}$

trước

before

'She ran home hurriedly.'

e. Lúc Tấm bước lên

time Tam step up

chỉ còn giỏ không

only still basket not

'When Tam came back and saw her empty basket,'

\section{f. bèn ngồi xuống bung mặt then sit down blind eyes}

khóc hu hu

weep noisily

'then she sat down and wept noisily.'

In this example, the first event (a) believing her sister's words-is built upon by the second-(b) going down to the pond and washing her hair-which is introduced by the preverbal bèn. This in turn is built on by event (c)-transferring the tiny shrimp from Tam's basket to Cam's basket - which is marked by the postverbal rồi. The postverbal rồi signals the completion of event (c) and introduces event (d) which builds upon event (c). Event (e) expressed in the adverbial clause is a background event which is followed by the foreground event (f) marked by bèn.

It can be seen that rồi, xong, and đoạn have a perfective or completive aspect whereas thì and bèn mark the beginning of a successive event. Besides rồi, xong, and đoạn, đã also has aspectual value. It has a perfective aspect since it refers to the action or event in its entirety. A clause on the narrative timeline which has the preverbal $đ \tilde{a}$ makes reference to its beginning and ending points so it has 
perfective aspect. The preverbal $d \tilde{a}$ is not a past tense marker since Vietnamese has no grammatical forms marking tenses. The timeframe of the narrative is usually in the past; therefore, the narrative is represented as having already taken place. So the clause having $d \tilde{a}$ has the perfective aspect in the past timeframe. The example in the previous section - Thấng này sang năm cuốn tù điển đã soan xong 'This month next year, the dictionary will have been finished' serves as a good example to support the fact that $d \tilde{a}$ is not a tense marker since it also occurs in future time. Consider the following example from the folktales having $đ \tilde{a}$ with perfective aspect.

$$
\begin{aligned}
& \text { Ngụa phóng một chốc đã } \\
& \text { horse run an instant COMP.MK } \\
& \text { đến kinh đô. } \\
& \text { arrive capital } \\
& \text { 'Soon she arrived at the capital.' }
\end{aligned}
$$

This sentence refers to an action which has been completed on the past timeframe of the narrative. It is viewed as a whole and makes reference to its beginning and ending points.

\section{Functions of Progression Mark- ers out of Narrative Timeline}

The progression markers which occur on the narrative timeframe function to introduce a new happening which occurs after the completion of the previous one. However it has also been found that these markers may occur out of the narrative timeline such as in quotations and flashback.

Grimes (1975) notes that a quotation gives collateral information which is defined as possible events with reference to projected time ${ }^{9}$. An act of speaking is an event itself but what is said usually is not. Quotations in the Vietnamese folktales have the form of prediction. They have an event sequence which is displaced forward in time as exemplified in example (12).

$$
\begin{aligned}
& \text { Tấm chì vào } \\
& \text { Tam only come in } \\
& \text { cái thùng thua: } \\
& \text { CLF basket speak }
\end{aligned}
$$

'Tam only put her head in the basket and said:

Dì con bắt phải
stepmother child force must
nhăt thóc
pick up unhusked rice out
thóc, gạ ra gạo,
unhusked rice out rice
rồi $\quad$ mói duợc
COMP.MK so get
di xem hộ
go watch festival

"My stepmother forced me to sort the rice. If I finish this work, I can go and join the festival.

Lúc nhăt xong thì
time pick up COMP.MK TOP.MK
hội dã
festival COMP.MK be over
rồi còn gì
COMP.MK still what
nũa mà $\quad$ xem.
further in order to watch
By that time, the festival will be
finished."'

In the above example, the progression markers rồi, xong, and đã mark a se-

\footnotetext{
${ }^{9}$ Projected time refers to the time when a situation or action is contemplated, enjoined or anticipated but not realized.
} 
quence of events that might result later from the main action. This sequence of events is foreshadowing, which is said before the events are actually asserted to have taken place. These markers in a quotation do not function to propel or develop narrative time so they do not mark the storyline.

Flashback is events or activities which are displaced backward in time. Flashback information is usually marked by the progression marker $đ \tilde{a}$ as in example (13).

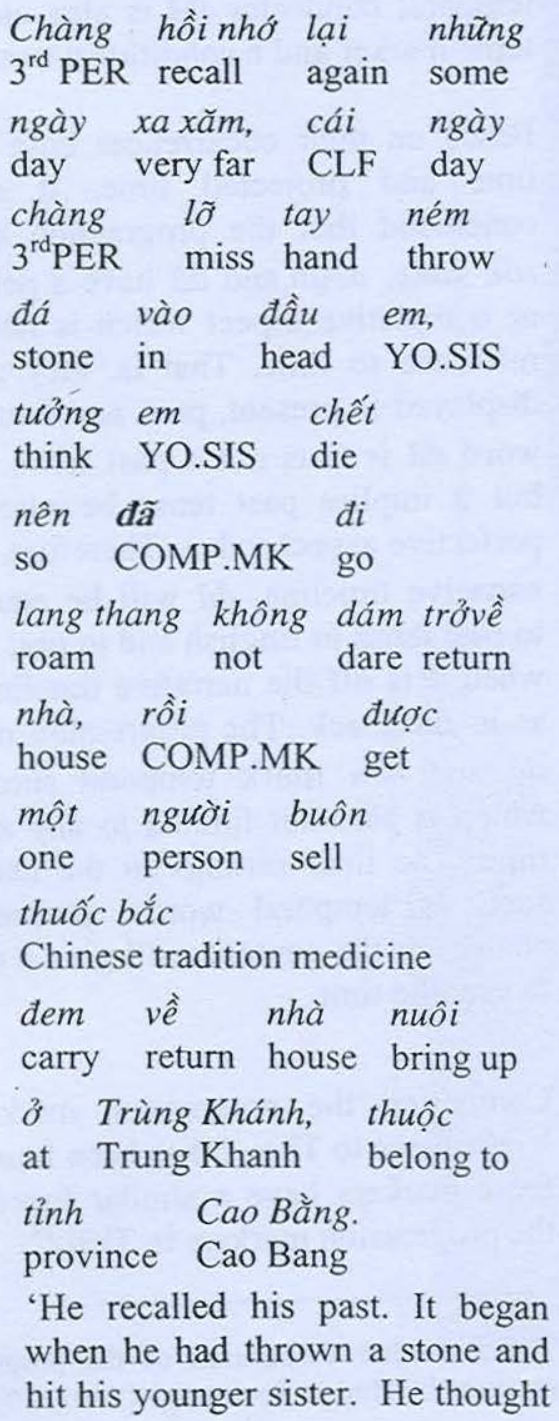

that she had died so he had run away. Gne day, he had met a herbal seller who brought him up at Trung Khanh, Cao Bang province.'

In this example the event-running away- has taken place in a previous part of the story. The preverbal $d \tilde{a}$ indicates that the event was completed in the distant past as seen in example (14). The postverbal $r \hat{o} i$ is also used to mark a sequence of events which is displaced backward in time.

Tô Văn thấy thế
To Van see like this
sộ quá, chạy thăng
afraid very run straight in
một mạch ra dường
one breath out way
không còn dám
no more dare
ngoái cổ
Turn one's head around again
'To Van was very frightened. He
immediately ran away from home
without turning back even one
time.'

The occurrences of progression markers out of the narrative timeline reveal that they bear a notion of completion which is neutral, i.e., not limited to any specific time, and can be displayed in present, past, and future. The context and pragmatic knowledge enable the reader to know the time which those markers display.

Besides indicating the temporal sequence of events, the sentence conjunctive thi is also used to mark a topic, as in example 
(12) above and to indicate a condition in a quotation as in example (14) below.

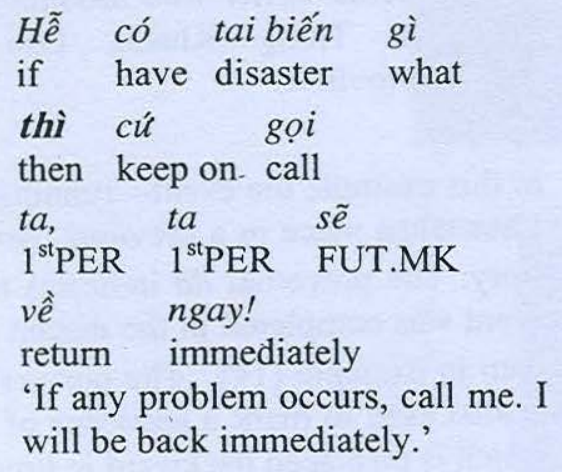

\section{Discussion}

The progression markers rồi, xong, đoạn, thì, bèn, and đã play a very important role in the folktales. An abstract of the folktales can be extracted by listing all the clauses having these markers. As progression markers, these words mark temporal sequences of events either in the narrative timeline or in projected time.

As the default timeframe of the narrative is past time or accomplished time, when these markers occur in past time, they indicate temporal succession and a causeeffect relationship of foregrounded events. The postverbal rồi, xong, and đoạn signal the completion of the previous events and introduce a new event which is chronologically tied to the previous one. The sentence connective thi and the preverbal bèn introduce the sentences which move the story forward and thus propel time: These two words have a similar function but different syntactic structure. The word bèn is always preverbal whereas thi occurs between two clauses. The preverbal bèn is rare and occurs only in texts whereas thì is normally used in everyday conversation. The preverbal $đ \tilde{a}$ which occurs with non-stative verbs indicates the thematic status of the following verb. Besides signaling foregrounded happenings, the preverbal $\tilde{a} \tilde{a}$ may also occur in flashback, which is information displaced backward in time. It indicates that an event has taken place in the previous part of the story.

In projected time as in a quotation, the progression markers mark the temporal sequence and a cause-effect relationship of events which have not occurred. Besides a progression marker, the temporal connector thì is also used as a topic marker and a conditional connector.

Based on their occurrences both in past time and projected time, it can be concluded that the progression markers rồi, xong, đoạn, and đã have a perfective or completive aspect which is neutral in reference to time. That is, they may be displayed in present, past, and future. The word $d \tilde{a}$ is thus not a past tense marker but it implies past tense because of its perfective aspect value. Therefore, on the narrative timeline, đã will be equivalent to past tense in English and to past perfect when it is off the narrative timeline such as in flashback. The progression markers thì and bèn mark temporal succession which is also not limited to any specific time. The time settings in the narrative, such as temporal words, phrases and clauses or the context, will give a clue as to specific time.

Comparing the progression markers in Vietnamese to Thai, it has been found that these markers have a similar function to the progression markers in Thai. ${ }^{10}$

${ }^{10}$ See further discussion of the progression markers in Thai in Somsonge (1991, 1992) 
Vietnamese Thai

$\begin{array}{lll}\text { rồi } & \text { lárw 'already' } \\ \text { xong } & \text { sèt } & \text { 'finish' } \\ \text { doạn } & \text { còp } & \text { 'end, terminate' } \\ \text { thì } & k \hat{s}: & \text { 'then' } \\ \text { bèn } & \text { cự } & \text { 'then, consequently' } \\ \text { dã } & d \hat{a}: j & \text { 'have experienced' }\end{array}$

In Thai the words læa'w 'already', sèt 'finish' còp 'end, terminate' and dâ.j 'have experienced' have perfective or completive aspect with no reference to specific time. The first three words indicate a completion of the preceding event and introduce a new event which is normally thematic. Compare example (16) showing the occurrence of $l æ: w$ in a Thai narrative with the use of rồi in example (10).

$$
\begin{aligned}
& \text { lẳcà:k khâ: sŭa tua } \\
& \text { after kill tiger CLS } \\
& \text { nán ta:j lǽw na:jphra:n } \\
& \text { that die already hunter }
\end{aligned}
$$

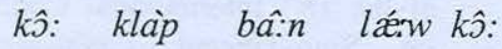

$$
\begin{aligned}
& \text { then return house and then } \\
& \text { paj- fâw phrára:cha: } \\
& \text { go meet king } \\
& \text { 'After (the hunter) had (already) } \\
& \text { killed the tiger, the hunter then } \\
& \text { returned home, and went to see } \\
& \text { the king.' } \\
& \text { (Somsonge, 1991: 108) }
\end{aligned}
$$

The preverbal $k \hat{s}$ : and $c u \eta \eta$ have a similar function to thì and bèn respectively. The preverbal cu $\eta$ behaves in a similar way to $k \hat{s}$; but it also implies a consequence of the previous event in the same way as $b e ̀ n$. The preverbal $k \hat{\jmath}$ : is used very frequently in narrative in the same manner as thì and it is regarded as equivalent to $k \hat{s}$ : in Thai ${ }^{11}$. However, their syntactic structure is different in that $k \hat{\jmath}$ : is always preverbal as seen in example (15) whereas thi occurs between two clauses. If the second clause has the same subject as the first one, it is usually omitted and the structure becomes the same as $k \hat{\rho}$ : as illustrated below.

$$
\begin{array}{ll}
\text { Thai } & {[\mathrm{NP}+\mathrm{VP}]_{\mathrm{CL} 1}} \\
& {[(\text { omitted NP) }+} \\
& k \hat{s}:+\mathrm{VP}]_{\mathrm{CL} 2} \\
\text { Vietnamese } & {[\mathrm{NP}+\mathrm{VP}]_{\mathrm{CL} 1}+\text { thi }+} \\
& {\left[(\text { omitted NP) }+\mathrm{VP}]_{\mathrm{CL} 2}\right.}
\end{array}
$$

Besides signaling the temporal sequence, $k \hat{j}$ : also functions as a conditional connector ${ }^{12}$ just as thì as illustrated below.

$$
\begin{aligned}
& \text { thâ: dèkdèk tham } \\
& \text { if children do } \\
& k a: n b a \hat{:} n \text { sèt } \\
& \text { homework finish } \\
& k \hat{s}: \quad c a ̀ \text { dâ:j } \\
& \text { then will have a chance } \\
& d u \text { : tho:rathát } \\
& \text { watch television } \\
& \text { 'If the children finish their home- } \\
& \text { work, they can watch television.' }
\end{aligned}
$$

In the same way as $đ \tilde{a}$, the preverbal $d \hat{a}: j$ is not a tense marker but implies past tense because it has perfective aspect value. It conveys a meaning that someone has experienced something either in the past or future time. It also has the same function as $d \tilde{a}$ in flashback. Compare example (18) in Thai with examples (1314) in Vietnamese.

\footnotetext{
${ }^{11}$ Compare the use of thì and $k \hat{\jmath}:$ in examples (4) and (16).

${ }^{12}$ See detailed discussion of multi-functions of the word $k \hat{s}$ : in Yajaj (1985).
} 


khǔn săn khॅ̌: raw
title San of our
nán pen khon
that be person
mânpur:n dâ:j
skillful shooting have
experienced

hàt hâj cha:w ba: yracan
train let people Bangrajan
jigpur:n

shoot

'Our San was skillful in shooting. $(\mathrm{He})$ had trained Bangrajan villagers to shoot.'

(Somsonge, 1991: 92)

The comparison of progression markers in Vietnamese and Thai shows that despite the morphological difference, at the level of discourse syntax, their discourse structures are quite common. It is therefore worth studying discourse structures of other Southeast Asian languages to explore the universal characteristics of discourse features.

\section{References}

Comrie, Bernard. 1981. Aspect. Cambridge: Cambridge University Press.

Dry, Helen Aristar. 1983. The Movement of Narrative Time. Journal of Literary Semantics 12.2:19-53.

Grimes, Joseph.1975. The Thread of Discourse. Hague: Mouton.

Hornby, A.S, E.V. Gatenby, and H. Wakefield. 1962. The Advanced Learner's Dictionary of Current English. London: Oxford University Press.

Longcare, Robert E. 1996. The Grammar of Discourse. New York and London: Plenum Press.
Nguayễn Ván Ngọ, Vũ Ngọ Phan, and Trầ Thanh Mại. 1996. Kho Tàng Truyện Cổ Tịch Việt Nam (A Collection of Vietnamese Folktales). Hanoi: Ván Học.

Somsonge Burusphat. 1991. The Structure of Thai Narrative. Dallas: Summer Institute of Linguistics and the University of Texas at Arlington publications in linguistics 98 .

Somsonge Burusphat. 1992. The Identification of Storyline in Thai Narrative Discourse. In Language in Context: Essays for Robert E. Longacre, ed. by Shin Ja J. Hwang and William R. Merrifield, pp.419433. Dallas: the Summer Institute of Linguistics and the University of Texas at Arlington.

Suksiri Danthanavanich. 2000. Cohesive devices in Vietnamese folktales. MA thesis, Mahidol University, Thailand.

Yajai Chuwicha. 1985. The Multi-Purpose Marker in Oral Narrative: A Discourse Analysis. Paper presented at the $18^{\text {th }}$ International Conference on Sino-Tibetan Language and Linguistics, Bangkok.

Viện Ngôn ng học. 1987. VietnameseEnglish Dictionary. TP. Hồ Chi Minh: Nha xuất bản TP. Hồ Chi Minh. 